\title{
Using Peptidomimetics and Constrained Peptides as Valuable Tools for Inhibiting Protein-Protein Interactions
}

\author{
Naomi S. Robertson (i) and David R. Spring * (it) \\ Department of Chemistry, University of Cambridge, Lensfield Road, Cambridge CB2 1EW, UK; nsr32@cam.ac.uk \\ * Correspondence: spring@ch.cam.ac.uk; Tel.: +44-1223-336498
}

Received: 27 March 2018; Accepted: 18 April 2018; Published: 19 April 2018

\begin{abstract}
Protein-protein interactions (PPIs) are tremendously important for the function of many biological processes. However, because of the structure of many protein-protein interfaces (flat, featureless and relatively large), they have largely been overlooked as potential drug targets. In this review, we highlight the current tools used to study the molecular recognition of PPIs through the use of different peptidomimetics, from small molecules and scaffolds to peptides. Then, we focus on constrained peptides, and in particular, ways to constrain $\alpha$-helices through stapling using both one- and two-component techniques.
\end{abstract}

Keywords: protein-protein interactions; peptidomimetics; proteomimetics; macrocycles; stapled peptides

\section{Introduction}

Protein-protein interactions (PPIs) are well-recognised as mediators of a plethora of processes in biological systems and are vitally important in the progression of many disease states [1-3]. There are estimates of between 130,000 to 650,000 relevant interactions in the human protein-protein interactome [4-6]. Many of these interactions are underexplored and so represent an emerging area for drug discovery. Through the study of PPIs, targets that were previously overlooked have now come to light as significant targets of interest.

This review will focus on the methods used to target PPIs, from small molecules, peptidomimetics and peptides and, in particular, constrained peptide macrocycles and stapled peptides.

\section{General Structure of PPIs}

The development of new therapeutics which target PPIs is inherently challenging for medicinal chemistry and chemical biology [7]. Most interactions are dynamic and occur over a relatively large protein contact surface area (1500 to $3000 \AA^{2}$ ) [8,9], much larger than the average contact area needed for small molecule binding, which is thought to be approximately 300 to $1000 \AA^{2}$ [10]. Additionally, PPIs have generally been thought of as undruggable because many protein-protein interfaces lack the obvious pockets for binding small molecules [11]. Constitutive PPIs tend to be predominantly driven by hydrophobic effects [1], while transient PPIs consist of more polar residues [12]. Proteins which have transient PPIs can often have more than one binding partner from a much larger protein family. A well-known example comes from the Bcl-2 family of proteins, where prosurvival members of the family interact with the proapoptotic BH3 (Bcl-2-homology-3)-only members [13].

While a PPI is usually large in size, not all residues contribute to binding equally and, in fact, only a small number of crucial amino acid residues within the PPI are important in delivering the vast majority of the binding affinity and specificity [14-18]. These regions have been termed 'hot spots'. Many of these have been elucidated through systematic alanine scanning mutagenesis, where a hot 
spot residue is established if, when that residue is mutated to an alanine, the binding energy difference is more than $2 \mathrm{kcal} / \mathrm{mol}$ [15]. Hot spots were found to be rich in residues such as arginine, tryptophan and tyrosine.

Although PPI hot spots are presented on the protein surface, these residues are generally not contiguous within the protein sequence as a result of protein folding. Many hot spots are associated with protein secondary structure motifs such as the $\alpha$-helix, $\beta$-sheet and $\beta$-turn. Of these secondary structures, the $\alpha$-helix has captured the interest of researchers. This is because $\alpha$-helices comprise approximately $60 \%$ of all secondary structures in protein complexes [18,19]. Additionally, $\alpha$-helices have been shown to mediate a large number of key therapeutically relevant PPI interfaces, of which $60 \%$ bind to one face of the helix [19]. At the protein-protein interface, $\alpha$-helices tend to bind into the groove of their binding partner, and as a result, helix mimetics have been of great interest. A number of methods exist which aid in the discovery of new PPIs and facilitate the discovery of molecules to bind PPIs, including high throughput screening [20], phage display [21], crosslinking [22], computational studies [23] and structural based design, to name a few.

\section{Methods for Targeting PPIs}

\subsection{Small Molecules and Peptidomimetics}

Traditionally, peptidomimetics have been subdivided into three types [24-26]. Type I mimetics are short peptides which mimic the secondary structure landscape of the parent peptide, with minor alterations to the sequence. Type II mimetics are non-peptidic functional molecules based on a scaffold that does not mimic the peptide secondary structure. Type III mimetics are also non-peptidic molecules and these match the spatial topology of key interaction motifs of the parent peptide. More recently, these categories have been further improved by Pelay-Gimeno et al. into four different classes: Classes A-D, where Class A mimetics are most similar to the parent peptide, while Class D mimetics show the least similarities [26]. Class A mimetics, like Type I mimetics, are peptides with minimal alterations to the peptide side chains and backbone. Class B mimetics, while still peptidic in nature, include much more dramatic backbone and side chain alterations (e.g., peptoids, $\beta$-peptides and $\alpha / \beta$-mixed peptides). Class $C$ mimetics are similar to Type II mimetics and involve a scaffold, from which substituents that are analogous to the peptide side chains are projected. Finally, Class D mimetics are those that mimic the mode of action of a peptide without a direct link to the peptide side chains.

Classical medicinal chemistry uses small molecule drugs which bind either into the active site of a protein, or at an allosteric position. However, as alluded to earlier, PPIs tend to be large and challenging to target with small molecules. Nevertheless, a number of small molecule PPI inhibitors have successfully been developed; including ABT-737 and ABT-236, which both inhibit the Bcl- $\mathrm{x}_{\mathrm{L}}$ /Bak PPI (Abott Laboratories) [27,28], along with the Nutlin family of small molecule compounds (Hoffmann-La Roche) and the benzodiazapinediones (Johnson \& Johnson Pharmaceuticals), which inhibit the p53/mDM2 PPI [29,30] (Figure 1). These are all examples of Class D mimetics.

Class C mimetics include scaffolds such as terphenyls, which were established by Hamilton and colleagues, and mimic one face of an $\alpha$-helix in order to target PPIs [31]. They developed a series of trisubstituted 3,2',2"-terphenyl compounds, the aryl cores of which adopt a staggered conformation (dihedral angles, $59.1^{\circ}$ and $120.7^{\circ}$ ) and thus mimic the $i, i+3, i+4$ and $i+7$ residues of a helix through the ortho positions of the scaffold [31]. In addition, other scaffolds such as terephthalamides [32], 4,4'-dicarboxamines [33], 5-6-5-imidazole-phenyl-thiazoles [34], trispyridylamines [35] and enaminones [36] have been developed as extended $\alpha$-helix mimetics by the Hamilton group. Other groups have reported their own scaffolds to mimic amino acid side chains on $\alpha$-helices. These scaffolds include picolinamides [37], pyridazines [38,39], phenyl-piperazine-triazines [40], pyrazines [41], 3-O-alkylated oligobenzamides [42] and 2-O-alkylated oligobenzamides [43] (Figure 2), and mimic one face of the helix. Notably, the Wilson group were the first to describe a solid-phase synthesis for an $\alpha$-helix mimetic with $N$-alkylated oligobenzamides, which act as 
inhibitors of p53/hDM2 [44,45]. The same group were also able to show orthogonal functionalisation of these non-peptidic helix mimetics through a copper-mediated 'click' chemistry approach [46].

Peptidomimetics that mimic more than one face of an $\alpha$-helix have also been explored. Both the Ahn and Hamilton groups converted a single faced bis-benzamide scaffold into a dual faced helix peptidomimetic (Figure 3) $[47,48]$. Additionally, an amphiphilic $\alpha$-helix mimetic based on a benzoylurea scaffold has been reported by Thompson and Hamilton [49], while Lee et al. developed two-face amphipathic $\alpha$-helix mimetics based on a triazine-piperazine-triazine scaffold [50] (Figure 3). The triazine-piperazine-triazine peptidomimetics showed improved binding affinity to Mcl-1 in a fluorescence anisotropy competition assay compared to a fluorescein labelled BH3 peptide. More drug-like proteomimetics based on a purine scaffold have also been reported by Lanning et al. (Figure 3) [51]. A number of other non-peptidic scaffolds have also been reported which mimic more than one face of the helix and a review of these has been published by Lanning and Fletcher [52].

A

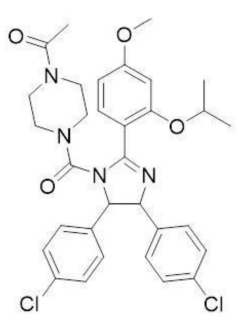

Nutlin-1

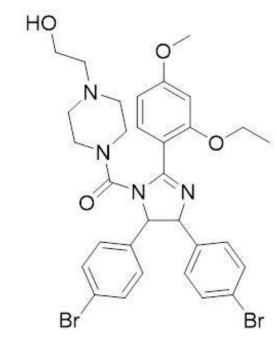

Nutlin-2

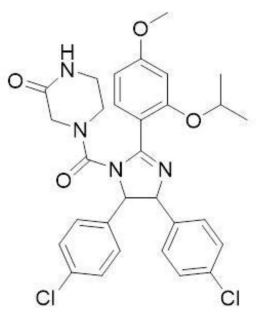

Nutlin-3

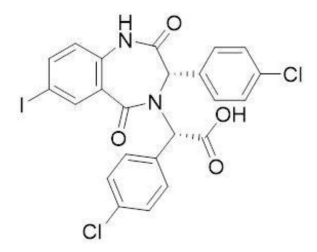

Benzodiazepinedione-1

B
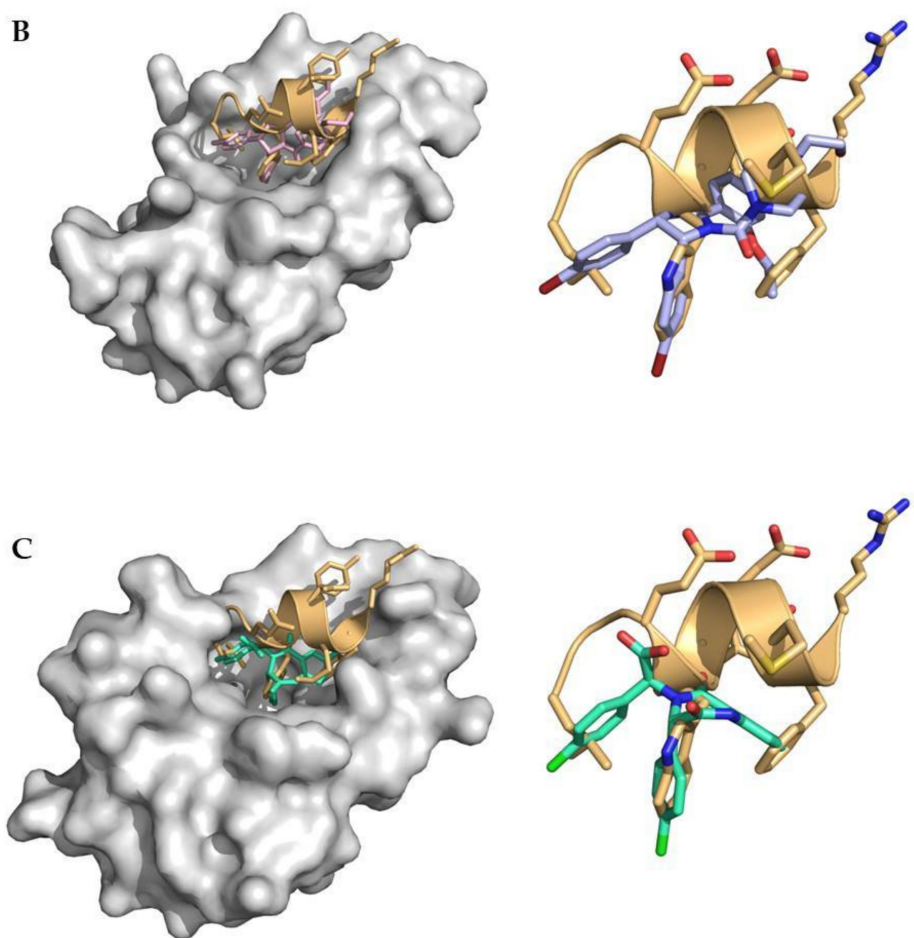

Figure 1. (A) Classic small molecule inhibitors of protein-protein interactions (PPIs) include the Nutlin family of small molecules (Nutlin-1, Nutlin-2 and Nutlin-3) and benzodiazepinediones; (B) crystal structure of Nutlin-2 bound in the p53 binding pocket of MDM2 (PDB 1RV1), overlaid with a p53 helix (PDB 1T4F) (left) and showing the overlap between Nutlin-2 and the side chain residues of p53; (C) crystal structure of benzodiazepinedione- 1 bound in the p53 binding pocket of MDM2 (PDB 1T4E), overlaid with a p53 helix (PDB 1T4F) (left) and showing the overlap between benzodiazepinedione-1 and the side chain residues of p53. 


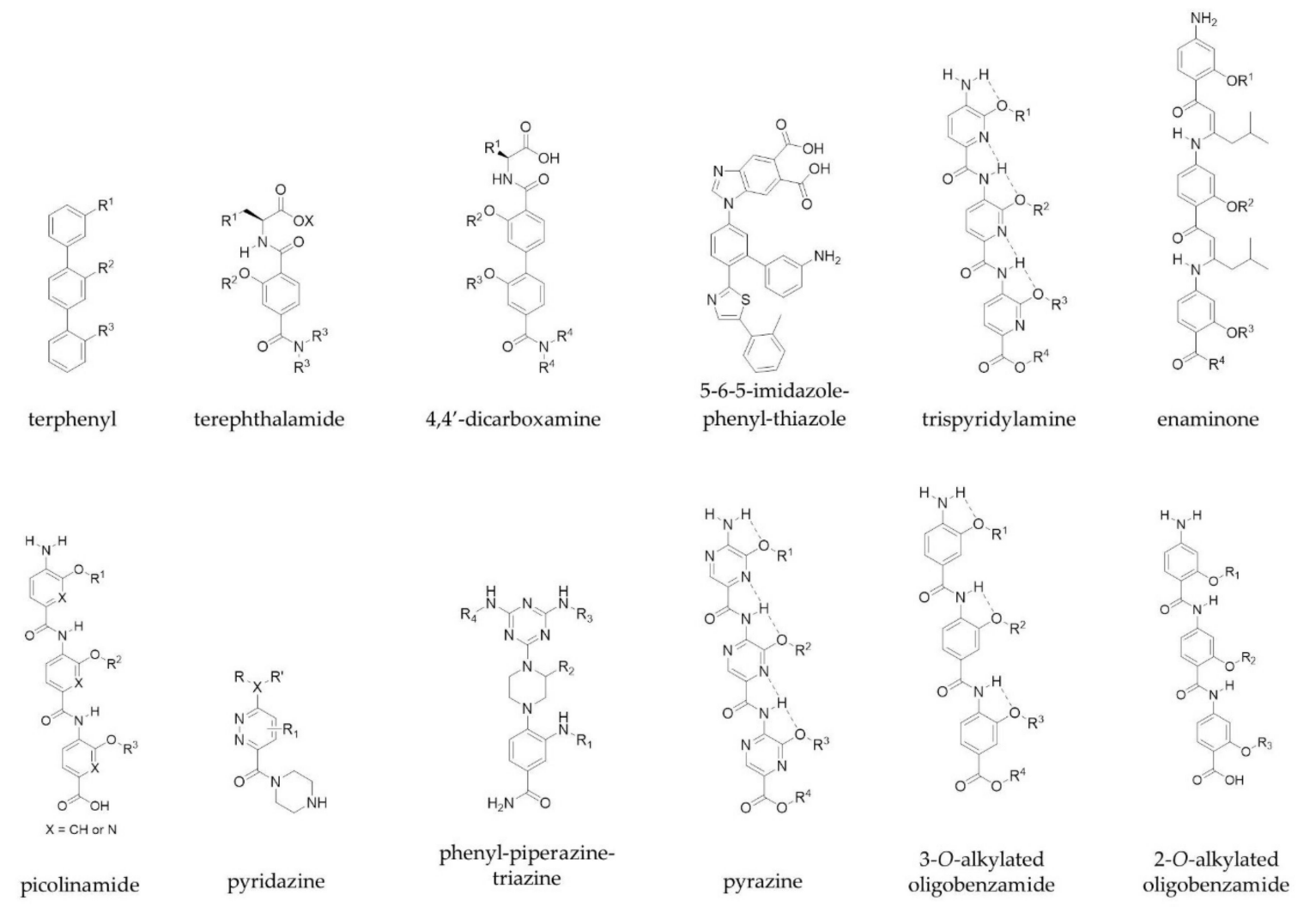

Figure 2. Examples of the proteomimetic scaffolds used to target PPIs. R groups mimic peptide side chains of hot spot residues.

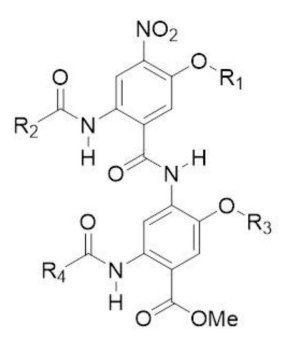

bis-benzamide

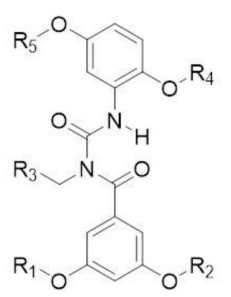

benzoylurea<smiles>[R]Nc1nc(N[R])nc(N2CCN(c3nc(N[R])nc(N[R])n3)C([R])C2)n1</smiles>

triazine-piperazinetriazine<smiles>[R]N(C(=O)OC(C)(C)C)c1nc(NCC(=O)O)c2ncn([R1])c2n1</smiles>

purine

Figure 3. Examples of multi-faced proteomimetic scaffolds used to target PPIs. R groups mimic peptide side chains of hot spot residues.

\subsection{Peptides to Target PPIs}

Short peptide sequences are associated with a number of problems. They often lack the ability to fold into their bioactive conformation because of an entropic penalty for folding and they are susceptible to faster rates of degradation due to proteolysis. Overcoming these difficulties frequently involves one or more of the following: incorporation of non-native amino acids [53], D-amino acids [54-57], and $\beta$-amino acids [58]; retro-inverso peptides [59]; changing the backbone (through $\mathrm{N}$-methylation [60], or the introduction of amide bond isosteres [61]); and cyclising strategies [62-65]. Non-native amino acids confer stability as a result of the proteolytic machinery in the cell being ill equipped to deal with unnatural amino acids [66]. Unnatural amino acids such as $\alpha$-aminobutyric acid (Aib or $\alpha$-methylalanine) can promote secondary structure formation ( $3_{10}$-helix), while other 
$\alpha, \alpha$-disubstituted amino acids, such as $\alpha$-pentenylalanine, can help form an $\alpha$-helix, owing to the Thorpe-Ingold effect [67]. Incorporation of D-amino acids also inverses the stereochemistry at the $\alpha$-carbon of the peptide backbone, and a fully retro-inverso peptide not only inverts the chirality of the peptide but also reverses its sequence. This in turn gives a peptide with the side chains projected in the correct orientation [68]. Backbone modifications such as N-methylation can alter the cis-trans configuration of the amide bond, affecting the conformational freedom of adjacent amino acids [26]. It also alters the hydrogen-bond pattern of the peptide through reducing the number of hydrogen bond donors. Other backbone modifications, such as the use of foldamers, $\beta$-peptides and peptoids can additionally infer both proteolytic and metabolic stability $[69,70]$. Cyclic peptides have improved metabolic stability compared with their linear counterparts and cyclisation introduces conformational constraints that can reduce the flexibility of the peptide, allowing for a reduced entropic cost upon binding, thus increasing binding affinity [66,71]. A few of the above peptide modifications will be discussed further in the following Sections.

\subsection{Macrocyclic Peptides}

Macrocyclic scaffolds are found in many natural products such as cyclosporine A, sunflower trypsin inhibitor (STF-1) and Rhesus $\theta$ defensin 1 (RTD-1); as a result, synthetic macrocycles have been widely investigated in the development of novel therapeutics and chemical probes $[26,72,73]$.

A number of pharmaceutical companies have macrocyclic peptides currently undergoing clinical trials for a range of targets. Examples include Polyphor, who have two drugs in clinical trials, Balixafortide (POL6326) (Figure 4) and POL6014; Bicycle Therapeutics, with bicyclic peptide BT1718; Apeptico, with Solnatide (AP301) (Figure 4); Ra Pharmaceuticals with RA101495; and Aileron Therapeutics, with two drugs, ALRN-5281 and ALRN-6924, also in clinical trials.

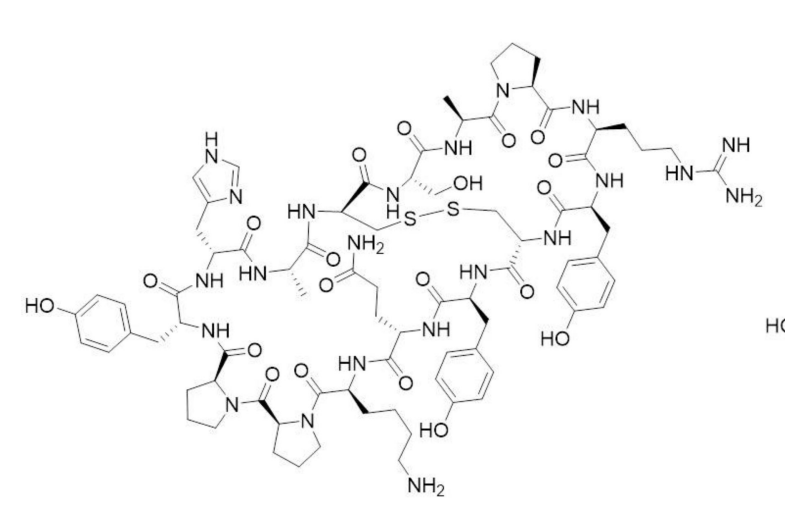

Balixafortide (POL6326)

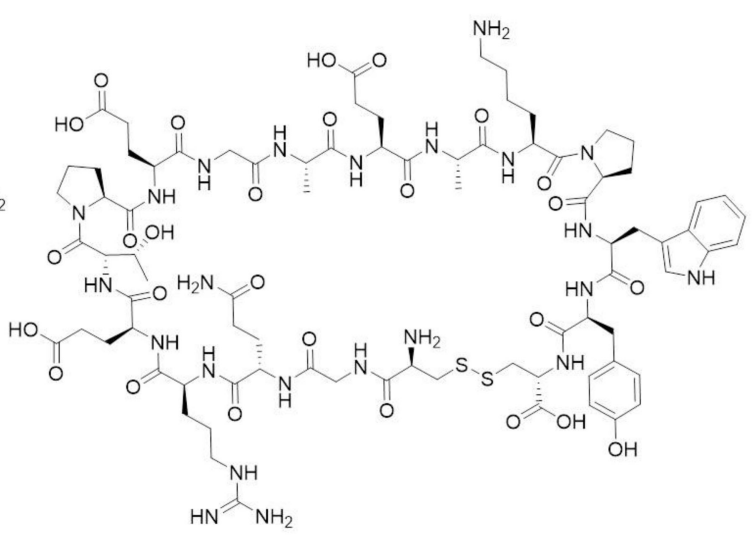

Solnatide (AP301)

Figure 4. Two examples of macrocyclic peptides (Class A PPI inhibitors) which are currently undergoing clinical trial studies as PPI inhibitors: Balixafortide (POL6326) from Polyphor and Solnatide (AP301) from Apeptico.

Balixafortide is a bicyclic peptide that is a potent and selective agonist of the chemokine receptor CXCR4. In combination with eribulin (Halaven ${ }^{\circledR}$ ), balixafortide has successfully completed a Phase 1 study for the treatment of advanced metastatic breast cancer and other oncology indications [74]. The structure of POL6014 has not yet been released, but the successful conclusion of its Phase 1 clinical study has recently been announced for the treatment of cystic fibrosis, non-cystic fibrosis bronchiectasis and alpha 1 antitrypsin deficiency [75].

BT1718, developed by Bicycle Therapeutics, has recently entered a Phase 1/2a study in solid tumours. It is a constrained bicyclic peptide which binds to membrane type 1-matrix metalloprotease (MT1-MMP; MMP14) and is a first-in-class bicyclic drug conjugate [76]. Developed by Apeptico, Solnatide has continued into Phase 2 clinical trials after a successful first-in-man study to assess the 
safety of the orally inhaled aerosol [77]. It is a cyclised peptide of the lectin-like domain on human TNF- $\alpha$ and an activator of ENaC-mediated $\mathrm{Na}^{+}$uptake for the treatment of pulmonary permeability oedema in acute respiratory distress syndrome (ARDS). Now in Phase 2 clinical trials for paroxysmal nocturnal hemoglobinuria, RA101495, developed by Ra Pharmaceuticals, is a potent cyclic peptide inhibitor of complement component 5 (C5) [78].

A subset of macrocycles is concerned with conformationally constraining $\alpha$-helices. This practice has been termed peptide stapling. Stapled peptides have recently come of age, with two compounds developed by Aileron Therapeutics in clinical trials.

\section{Stapled Peptides}

In general, the entropy of folding is the limiting factor for short isolated peptide sequences to fold into their bioactive conformation. Consequently, the stabilisation of these peptides has been studied extensively. However, additional factors such as the entropy contribution made by the desolvation of water molecules has also been shown to be important [79]. Synthetically constraining a peptide can reduce the entropy of folding, however, it may also restrict the peptide from folding into the correct conformation for binding $[79,80]$. Even so, for $\alpha$-helical peptides, 'stapling' has come to the forefront as a viable method of introducing constraints, where the side chains of two residues in the peptide are covalently linked to form a macrocycle. Peptide stapling can increase $\alpha$-helical character, protease stability, binding affinity and promote cell penetration when compared to their unmodified counterparts [81].

There are an abundance of different techniques that have been developed for peptide stapling. The different methods for peptide stapling can be divided into two subsets: one-component stapling, where the side chains of two amino acids are directly linked; and two-component stapling, where the sides chains of two amino acids are connected through a linker.

\subsection{One-Component Stapling}

One-component stapling methods have been developed to allow the use of both natural (e.g., lysine, glutamic acid etc.) and non-natural (e.g., alkenyl and azido amino acids) amino acids as a stapling anchor. The earliest form of stapling did not involve covalent linkage, but instead used salt bridges between complementarily charged residues, particularly lysine and glutamic acid residues [82]. However, with these peptides, the environment the peptide occupies plays a role in inducing the peptide conformation, thus care must be taken to control both $\mathrm{pH}$ and salt concentrations [83]. Since salt bridges, a number of other one-component stapling techniques have been reported, including lactamisation [84-86], triazoles [87] and all-hydrocarbon stapling [79,88-93], to name a few.

Rosenblatt and co-workers introduced the idea of lactam staples, where the proteinogenic amino acids lysine and aspartic acid at $i$ and $i+4$ positions on a short sequence of parathyroid-hormone-related protein (PTHrP) were cyclised [84]. Lactamisation has since been systematically studied by Fairlie and co-workers on simple pentapeptides, where they showed that a single lactam bridge could effectively stabilise short $\alpha$-helical peptides, while also being aqueous stable [94]. Additionally, they demonstrated the use of consecutive lactam bridges to constrain $\alpha$-helices [95]. With these data in hand, Fairlie and co-workers applied this stapling strategy to a number of biologically relevant targets, including doubly lactam-stapled peptide analogues of hormone nociception, which induced greater levels of ERK phosphorylation in cells and thermal analgesia in mice [96].

'Click chemistry' was introduced by Sharpless in 2001 [97], and from the initial use of the Huisgen 1,3-dipolar cycloaddition on peptides by Meldal and co-workers, the copper catalysed azide alkyne click (CuAAC) reaction has catapulted into everyday use [98]. A notable one-component example of $\mathrm{CuAAC}$ comes from Kawamoto et al. who carried out a systematic study on the effect of linker length, position of the staple within the peptide and the effect of stereoisomers for the residue used for stapling [87]. They found that for an $i, i+4$ triazole stapled peptide, the best binding affinity peptide for 
targeting the $\beta$-catenin/B-cell CLL/lymphoma 9 (BCL9) PPI, was where the residues used for stapling were L-amino acids. This peptide also gave the greatest increase in helicity.

An interesting example of one-component stapling comes from Yamagishi et al. who reported a cyclisation strategy which involved the oxidative coupling of 5-hydroxyindole and benzylamine, which were introduced into the peptide through non-proteinogenic amino acids [99]. The cyclisation of a non-fluorescent peptide occurred rapidly at room temperature after the addition of $\mathrm{K}_{3} \mathrm{Fe}(\mathrm{CN})_{6}$ to generate a conjugated, heterocyclic linker structure which conferred fluorescence. Here, the linker not only acts as a peptide constraint but also as a fluorescent probe.

The current 'gold standard' for one-component stapling is the all-hydrocarbon staple, pioneered by Miller, Blackwell and Grubbs in the late 90s [100-102]. The field has since erupted through the work of the Verdine and Walensky groups [81,88,92,103-105]. All-hydrocarbon stapling relies on using the ruthenium catalysed ring closing metathesis reaction to form the staple macrocycle. Unnatural alkenyl amino acids which can be difficult to synthesise are also required for this ring closing strategy [106]. These are likely to be $\alpha, \alpha$-disubstituted amino acids, though some examples have been reported using monosubstituted alkenyl amino acids $[107,108]$. The most widely used all-hydrocarbon staple constrains $\alpha$-helical peptides across a single turn $(i, i+4)$. However, $i, i+3[90,109]$ and $i, i+7$ [89] have also been reported, as well as doubly stapled [110] and stitched stapled peptides [111].

The importance of all-hydrocarbon stapling has recently been highlighted as the result of ALRN-5281, a long-acting growth-hormone-releasing hormone agonist for the treatment of orphan endocrine diseases, successfully completing its Phase I clinical trial [112]. Additionally, Aileron Therapeutics also have another stapled peptide drug (ALRN-6924) in Phase I clinical trials for solid tumours and in Phase II trials for lymphoma and peripheral T-cell lymphoma [113,114]. ALRN-6924 is a stapled peptide designed to disrupt integration between the p53 tumour suppression protein and inhibition by murine double minute 2 (MDM2) and murine double minute X (MDMX). The results for these studies should be released in July 2018.

\subsection{Two-Component Stapling}

A number of two-component stapling techniques have been reported including photocontrollable macrocycles [115-118] and the use of bridging motifs like alkyl chains [119,120], aromatics [120-124], perfluoroaryl [125] and tetrazine [126]. These examples have been carried out using the natural amino acid cysteine as an attachment point (Figure 5), but other examples have also been reported for two-component stapling using lysine and tryptophan residues $[127,128]$ and non-native amino acids containing alkyne functionalities [129-133]. Cysteine has been exploited for two-component stapling partly due to the high nucleophilicity of the sulfhydryl group which can readily undergo alkylation with suitable electrophiles such as $\alpha$-halocarbonyls and Michael acceptors [134]. An excellent review on stapling using cysteine crosslinking has been published by Fairlie and de Araujo [135].

The ability to control the activity of a peptide through an external stimulus, such as light, has led to the development of photocontrollable macrocycles, introduced by the Woolley group [115-117]. Photosensitive azobenzene linkers were installed to give macrocycles across the $i, i+4, i, i+7$ or $i, i+11$ positions on the peptide sequence. The trans-to-cis isomerisation of the azobenzene linker produced a conformational change in the peptide to give either an $\alpha$-helix or random coil. Furthermore, the Woolley group employed a structurally rigid ethylene-based linker to stabilise across $i, i+11$ (three turns) of an $\alpha$-helix [136]. For a comprehensive review on the azobenzene photocontrol of peptides and proteins, see Mart and Allemann [137].

DeGrado and Greenbaum showed that an aromatic linker such as dibromo-m-xylene reacts with the sulfhydryl cysteine side chain in a simple one-pot reaction, both in solution and on solid support to constrain an $\alpha$-helical peptide and increase its helicity [120]. This strategy was applied to the stapling of calpain probes to mimic a natural PPI of cysteine proteases with good potency and selectivity. Another S-alkylation approach comes from Micewicz et al., who synthesised analogues of a potent dual-specific antagonist of p53-MDM2/MDMX interactions, PMI-N8A [124]. They showed the stapled 
peptide to be cell-permeable and displayed potent anticancer activity at a low dose $(0.3 \mathrm{mg} / \mathrm{kg}) \mathrm{against}$ a human colorectal cancer cell line.

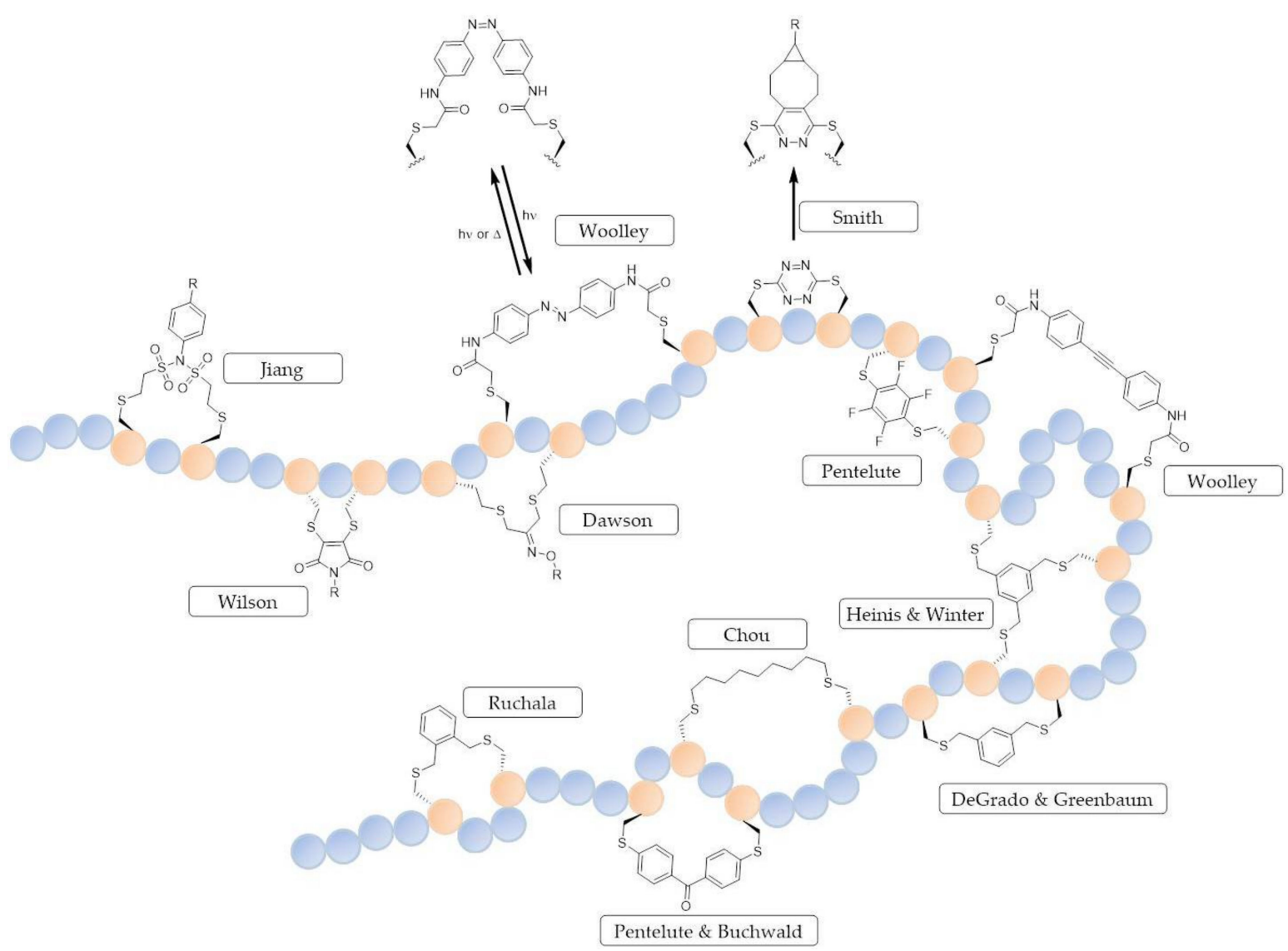

Figure 5. Some of the reported two-component cysteine cyclisation strategies, where $\mathrm{R}=$ different functional tags and handles.

Bicyclic peptides linked through cysteine residues are of great interest, especially with the clinical trial of a bicyclic peptides developed by Bicycle Therapeutics. The initial work on this strategy was carried out by Heinis and Winter, where a series of peptides with three reactive cysteine residues, spaced by six amino acids, were synthesised and fused to the phage gene-3-protein. The peptides were then conjugated with 1,3,5-tris(bromomethyl)benzene under mild aqueous conditions to generate a series of bicyclic peptides covalently attached to the mesitylene core [138]. This approach has been used to synthesise a potent and selective inhibitor of human urokinase-type palasminogen activator (uPA) [139]. Apart from tris(bromomethyl)benzene, a number of other small molecule linkers with thiol-reactive groups have been reported [140].

Dichloroacetone (DCA) was incorporated as a staple linkage by Assem et al. to enhance helical secondary structure [141]. Following stapling, the ketone moiety of the linker was then modified with a diverse range of molecular tags (fluorophore, CPP etc.) through oxime ligation. Additionally, a second macrocycle was formed through the cyclisation of an $N$-terminal aminooxy group with the acetone linker.

A rapid and reversible two-component stapling methodology, using cysteine or homocysteine as the peptide anchoring amino acids, has recently been reported by Grison et al. [142]. The staple is formed through employment of a dibromomaleimide, which can be further functionalized by 'click' chemistry. This reversible approach has been hypothesised to allow for the delivery of a peptide-based reagent into the cell, where the constraint can be removed, and thus the peptide is less readily transported out of the cell [142]. 
Tetrazine staples were installed as a constraint by Brown and co-workers through the use of a dichlorotetrazine linker reacting with two cysteine residues between two and 27 residues apart [126]. Additionally, they functionalized the linker following macrocyclisation with the use of an octyne-derived fluorescein probe through an inverse-electron demand Diels-Alder reaction. Another $\mathrm{S}_{\mathrm{N}}$ Ar linker has been reported by the Pentelute group using a perfluoroaryl linker, which has the benefit that the peptide is adorned with NMR-detectable ${ }^{19} \mathrm{~F}$ atoms which is a useful analytical tool [125]. In addition, the Pentelute and Buchwald groups have expanded on the $\mathrm{S}_{\mathrm{N}}$ Ar bioconjugation methodology with the use of a bis-palladium complexed benzophenone [122].

Photoinduced coupling of cysteines and alkenes, also known as thiol-ene coupling, has recently been investigated by Wang and Chuo using an $\alpha, \omega$-diene, while using an initiator with irradiation at $365 \mathrm{~nm}$ to install a thioether linkage across $i, i+4, i, i+7$ and $i, i+8$ positions [119]. More recently, $\mathrm{N}$-phenyl-divinylsulfonamides have been investigated for two-component cysteine stapling by Li et al., where they treated oxytocin with $p-\mathrm{CH}_{3} \mathrm{O}-\mathrm{N}$-phenyldivinylsulfonamide linkers functionalized with different handles [143].

An intramolecular tryptophan condensation approach for peptide stapling was recently reported by Hui et al. using an aldehyde under mild acidic conditions [128]. The tryptophan residues were linked at the C2 position of the indole to give a variety of $i, i+n$ (where $n=1,2,3$ or 4 ) stapled peptides.

As alluded to in some of the examples above, unlike one-component stapling techniques, two-component stapling also offers the ability to create a diverse series of peptides, by carrying out a late stage functionalisation through the use of different linkers (Figure 6).

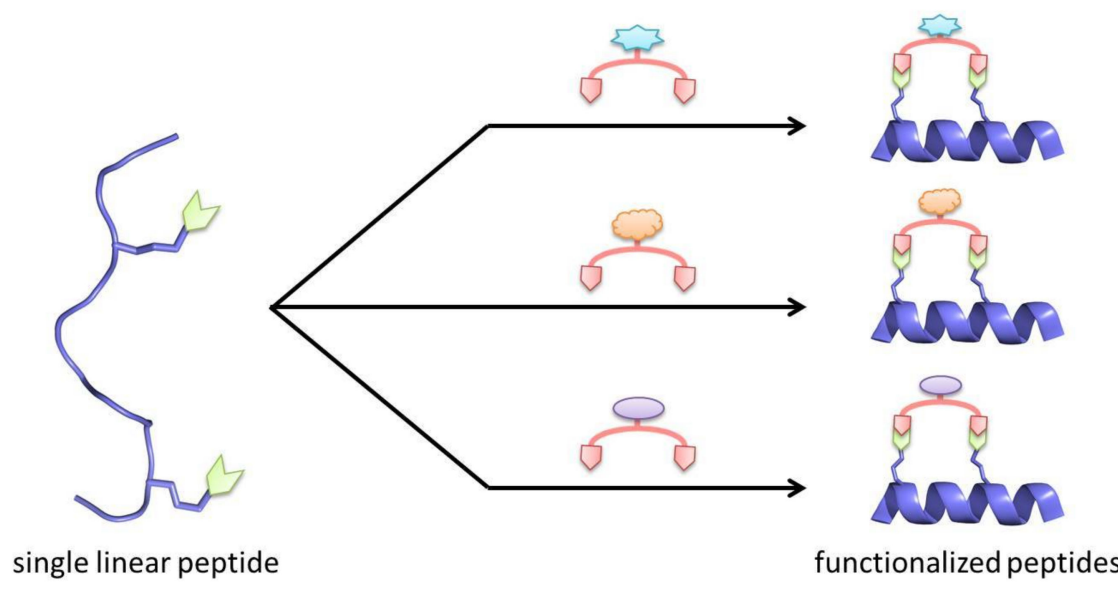

Figure 6. From a single synthesised linear peptide, a large library of functionalized stapled peptides can be made through the use of a variety of linkers, which can include fluorophores, cell penetrating peptides and handles for pull down assays.

The Spring laboratory has pioneered a two-component peptide stapling technique based on the CuAAC reaction, which has been termed a double-click staple, where a bis-alkynyl linker is reacted with two azido containing amino acids forming two triazoles [129,144]. For this strategy, a number of different linkers (linear aliphatic and aromatic, Figure 7) have been employed through the help of molecular dynamics to target a variety of different PPIs. These include helical peptides to target the p53/MDM2 interaction $[129,145,146]$, non-helical constrained peptides of transcription factor hepatocyte nuclear factor $1 \beta(\mathrm{HNF} 1 \beta)$ to target a key PPI in ovarian cancer [147], a macrocyclic peptide to inhibit the substrate recognition domain of tankyrase [148], and an $i, i+6$ stapled helical peptide to target the genome-stability hub CTF4 [131]. A similar synthetic double-click approach has also been adopted by the Thurber group, who have reported a stabilised fluorescent GLP-1 receptor ligand exendin [133,149]. More recently, Pedersen and co-workers reported a third generation CuAAC stapling and functionalisation strategy which uses a triyne linker to give a double-clicked stapled peptide, the linker of which can then be further functionalized through another CuAAC reaction [150]. 
<smiles>C#CCCCC#C</smiles><smiles>C#CCNC(=O)NCC#C</smiles>

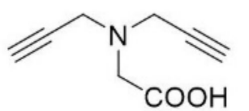<smiles>C#CCCCCC#C</smiles><smiles>C#CCCNC(=O)NCCC#C</smiles><smiles>C#Cc1cc(C#C)cc(C(=O)O)c1</smiles><smiles>C#CCCCCCCC#C</smiles><smiles>C#CCCCNC(=O)NCCC#C</smiles><smiles>C#Cc1ccc2ccc(C#C)cc2c1</smiles>

Figure 7. Examples of linkers that have been used for the two-component copper catalyzed azide-alkyne double-click reaction.

A copper free biorthogonal double strain-promoted stapling technique was also reported, which eliminates the need for the potentially toxic copper catalyst [132]. Additionally, the copper-free strategy allows for in situ stapling to generate a large library of stapled peptides directly in the assay medium in a 96-well plate.

\section{Conclusions}

Since the identification of PPIs as potential targets for therapeutics, we have witnessed their impressive journey to fame, from undruggable targets to being in the spotlight. As a result, studies into PPI stabilisers and inhibitors have increased significantly.

Although challenging, the use of small molecule PPI inhibitors has become more commonplace. Classical small molecule and peptidomimetic PPI inhibitors tend to mimic peptide sidechains to take advantage of the binding affinity of a number of hot spot residues. The cyclisation of peptides to form macrocycles has proven itself to be a valuable tool in increasing the stability of peptides in cells and in some cases also increasing the binding affinity of these peptides for their targets.

In an effort to target PPIs, stapled peptides have recently come of age, especially two stapled peptide drugs going into clinical trials. Although the gold standard for peptide stapling still remains the all-hydrocarbon staples, more and more stapling techniques are being reported to overcome some of the pitfalls of the all-hydrocarbon staple, including the need for expensive amino acids which are synthetically challenging to make and a catalyst requirement. Two-component stapling strategies are also growing in popularity due to the ease of creating a library of functionalized peptides through variation of the linker. Additionally, different approaches for stapling cysteine residues have increased in popularity, helped by the fact that there is no requirement for using non-proteinogenic amino acids. An important note is that with the wide variety of two-component cysteine stapling methodologies, a toolbox of linkers is available to use which allows researchers to specifically choose the most appropriate linkers for the job at hand, whether it be reversible [142], rigid [136], or attached to a functional handle (e.g., fluorophore, biotin etc.) [141-143]. Overall, in the next few decades, we foresee a series of interesting solutions to the challenges still faced by those working in the field of peptidomimetics to target PPIs.

Acknowledgments: This work was supported by the EPSRC Fellowship (EP/P020291/1).

Conflicts of Interest: The authors declare no conflict of interest. 


\section{References}

1. Keskin, O.; Gursoy, A.; Ma, B.; Nussinov, R. Principles of protein-protein interactions: What are the preferred ways for proteins to interact? Chem. Rev. 2008, 108, 1225-1244. [CrossRef] [PubMed]

2. Ryan, D.P.; Matthews, J.M. Protein-protein interactions in human disease. Curr. Opin. Struct. Biol. 2005, 15, 441-446. [CrossRef] [PubMed]

3. Gonzalez, M.W.; Kann, M.G. Chapter 4: Protein Interactions and Disease. PLoS Comput. Biol. 2012, 8, e1002819. [CrossRef] [PubMed]

4. Stumpf, M.P.H.; Thorne, T.; de Silva, E.; Stewart, R.; An, H.J.; Lappe, M.; Wiuf, C. Estimating the size of the human interactome. Proc. Natl. Acad. Sci. USA 2008, 105, 6959-6964. [CrossRef] [PubMed]

5. Venkatesan, K.; Rual, J.-F.; Vazquez, A.; Stelzl, U.; Lemmens, I.; Hirozane-Kishikawa, T.; Hao, T.; Zenkner, M.; Xin, X.; Goh, K.-I.; et al. An empirical framework for binary interactome mapping. Nat. Methods 2009, 6, 83-90. [CrossRef] [PubMed]

6. Bonetta, L. Protein-protein interactions: Interactome under construction. Nature 2010, 468, 851-854. [CrossRef] [PubMed]

7. Yin, H.; Hamilton, A.D. Strategies for targeting protein-protein interactions with synthetic agents. Angew. Chem. Int. Ed. 2005, 44, 4130-4163. [CrossRef] [PubMed]

8. Jones, S.; Thornton, J.M. Principles of protein-protein interactions. Proc. Natl. Acad. Sci. USA 1996, 93, 13-20. [CrossRef] [PubMed]

9. Conte, L.L.; Chothia, C.; Janin, J. The atomic structure of protein-protein recognition sites. J. Mol. Biol. 1999, 285, 2177-2198. [CrossRef] [PubMed]

10. Wells, J.A.; McClendon, C.L. Reaching for high-hanging fruit in drug discovery at protein-protein interfaces. Nature 2007, 450, 1001-1009. [CrossRef] [PubMed]

11. Cukuroglu, E.; Engin, H.B.; Gursoy, A.; Keskin, O. Hot spots in protein-protein interfaces: Towards drug discovery. Prog. Biophys. Mol. Biol. 2014, 116, 165-173. [CrossRef] [PubMed]

12. La, D.; Kong, M.; Hoffman, W.; Choi, Y.I.; Kihara, D. Predicting permanent and transient protein-protein interfaces. Proteins 2013, 81, 805-818. [CrossRef] [PubMed]

13. Dutta, S.; Gullá, S.; Chen, T.S.; Fire, E.; Grant, R.A.; Keating, A.E. Determinants of BH3 Binding Specificity for Mcl-1 versus Bcl-xL. J. Mol. Biol. 2010, 398, 747-762. [CrossRef] [PubMed]

14. Clackson, T.; Wells, J.A. A hot spot of binding energy in a hormone-receptor interface. Science 1995, 267, 383-386. [CrossRef] [PubMed]

15. Bogan, A.A.; Thorn, K.S. Anatomy of hot spots in protein interfaces. J. Mol. Biol. 1998, 280, 1-9. [CrossRef] [PubMed]

16. Keskin, O.; Ma, B.; Nussinov, R. Hot regions in protein-Protein interactions: The organization and contribution of structurally conserved hot spot residues. J. Mol. Biol. 2005, 345, 1281-1294. [CrossRef] [PubMed]

17. Guharoy, M.; Chakrabarti, P. Secondary structure based analysis and classification of biological interfaces: Identification of binding motifs in protein-protein interactions. Bioinformatics 2007, 23, 1909-1918. [CrossRef] [PubMed]

18. Jochim, A.L.; Arora, P.S. Systematic analysis of helical protein interfaces reveals targets for synthetic inhibitors. ACS Chem. Biol. 2010, 5, 919-923. [CrossRef] [PubMed]

19. Raj, M.; Bullock, B.N.; Arora, P.S. Plucking the high hanging fruit: A systematic approach for targeting protein-protein interactions. Bioorg. Med. Chem. 2013, 21, 4051-4057. [CrossRef] [PubMed]

20. Taylor, I.R.; Dunyak, B.M.; Komiyama, T.; Shao, H.; Ran, X.; Assimon, V.A.; Kalyanaraman, C.; Rauch, J.N.; Jacobson, M.P.; Zuiderweg, E.R.P.; et al. High Throughput Screen for Inhibitors of Protein-Protein Interactions in a Reconstituted Heat Shock Protein 70 (Hsp70) Complex. J. Biol. Chem. 2018, 293, 4014-4025. [CrossRef] [PubMed]

21. Ting, J.P.; Tung, F.; Antonysamy, S.; Wasserman, S.; Jones, S.B.; Zhang, F.F.; Espada, A.; Broughton, H.; Chalmers, M.J.; Woodman, M.E.; et al. Utilization of peptide phage display to investigate hotspots on IL-17A and what it means for drug discovery. PLoS ONE 2018, 13, e0190850. [CrossRef] [PubMed]

22. Suchanek, M.; Radzikowska, A.; Thiele, C. Photo-leucine and photo-methionine allow identification of protein-protein interactions in living cells. Nat. Methods 2005, 2, 261-268. [CrossRef] [PubMed] 
23. Melagraki, G.; Ntougkos, E.; Rinotas, V.; Papaneophytou, C.; Leonis, G.; Mavromoustakos, T.; Kontopidis, G.; Douni, E.; Afantitis, A.; Kollias, G. Cheminformatics-aided discovery of small-molecule Protein-Protein Interaction (PPI) dual inhibitors of Tumor Necrosis Factor (TNF) and Receptor Activator of NF- $\mathrm{B}$ Ligand (RANKL). PLoS Comput. Biol. 2017, 13, e1005372. [CrossRef] [PubMed]

24. Ripka, A.S.; Rich, D.H. Peptidomimetic design. Curr. Opin. Chem. Biol. 1998, 2, 441-452. [CrossRef]

25. Azzarito, V.; Long, K.; Murphy, N.S.; Wilson, A.J. Inhibition of $\alpha$-helix-mediated protein-protein interactions using designed molecules. Nat. Chem. 2013, 5, 161-173. [CrossRef] [PubMed]

26. Pelay-Gimeno, M.; Glas, A.; Koch, O.; Grossmann, T.N. Structure-Based Design of Inhibitors of Protein-Protein Interactions: Mimicking Peptide Binding Epitopes. Angew. Chem. Int. Ed. 2015, 54, 8896-8927. [CrossRef] [PubMed]

27. Lee, E.F.; Czabotar, P.E.; Smith, B.J.; Deshayes, K.; Zobel, K.; Colman, P.M.; Fairlie, W.D. Crystal structure of ABT-737 complexed with Bcl-xL: Implications for selectivity of antagonists of the Bcl-2 family. Cell Death Differ. 2007, 14, 1711-1713. [CrossRef] [PubMed]

28. Tse, C.; Shoemaker, A.R.; Adickes, J.; Anderson, M.G.; Chen, J.; Jin, S.; Johnson, E.F.; Marsh, K.C.; Mitten, M.J.; Nimmer, P.; et al. ABT-263: A potent and orally bioavailable Bcl-2 family inhibitor. Cancer Res. 2008, 68, 3421-3428. [CrossRef] [PubMed]

29. Vassilev, L.T.; Vu, B.T.; Graves, B.; Carvajal, D.; Podlaski, F.; Filipovic, Z.; Kong, N.; Kammlott, U.; Lukacs, C.; Klein, C.; et al. In vivo activation of the p53 pathway by small-molecule antagonists of MDM2. Science 2004, 303, 844-848. [CrossRef] [PubMed]

30. Grasberger, B.L.; Lu, T.; Schubert, C.; Parks, D.J.; Carver, T.E.; Koblish, H.K.; Cummings, M.D.; LaFrance, L.V.; Milkiewicz, K.L.; Calvo, R.R.; et al. Discovery and cocrystal structure of benzodiazepinedione HDM2 antagonists that activate p53 in cells. J. Med. Chem. 2005, 48, 909-912. [CrossRef] [PubMed]

31. Orner, B.P.; Ernst, J.T.; Hamilton, A.D. Toward Proteomimetics: Terphenyl Derivatives as Structural and Functional Mimics of Extended Regions of an $\alpha$-Helix. J. Am. Chem. Soc. 2001, 123, 5382-5383. [CrossRef] [PubMed]

32. Yin, H.; Lee, G.-I.; Sedey, K.A.; Rodriguez, J.M.; Wang, H.-G.; Sebti, S.M.; Hamilton, A.D. Terephthalamide derivatives as mimetics of helical peptides: Disruption of the Bcl-x(L)/Bak interaction. J. Am. Chem. Soc. 2005, 127, 5463-5468. [CrossRef] [PubMed]

33. Rodriguez, J.M.; Nevola, L.; Ross, N.T.; Lee, G.; Hamilton, A.D. Synthetic inhibitors of extended helix-protein interactions based on a biphenyl 4,4'-dicarboxamide scaffold. Chembiochem 2009, 10, 829-833. [CrossRef] [PubMed]

34. Cummings, C.G.; Ross, N.T.; Katt, W.P.; Hamilton, A.D. Synthesis and biological evaluation of a 5-6-5 imidazole-phenyl-thiazole based alpha-helix mimetic. Org. Lett. 2009, 11, 25-28. [CrossRef] [PubMed]

35. Ernst, J.T.; Becerril, J.; Park, H.S.; Yin, H.; Hamilton, A.D. Design and application of an alpha-helix-mimetic scaffold based on an oligoamide-foldamer strategy: Antagonism of the Bak BH3/Bcl-xL complex. Angew. Chem. Int. Ed. 2003, 42, 535-539. [CrossRef] [PubMed]

36. Adler, M.J.; Scott, R.T.W.; Hamilton, A.D. Enaminone-based mimics of extended and hydrophilic $\alpha$-helices. Chemistry 2012, 18, 12974-12977. [CrossRef] [PubMed]

37. Yap, J.L.; Cao, X.; Vanommeslaeghe, K.; Jung, K.-Y.; Peddaboina, C.; Wilder, P.T.; Nan, A.; MacKerell, A.D.; Smythe, W.R.; Fletcher, S. Relaxation of the rigid backbone of an oligoamide-foldamer-based $\alpha$-helix mimetic: Identification of potent Bcl-xL inhibitors. Org. Biomol. Chem. 2012, 10, 2928-2933. [CrossRef] [PubMed]

38. Biros, S.M.; Moisan, L.; Mann, E.; Carella, A.; Zhai, D.; Reed, J.C.; Rebek, J. Heterocyclic alpha-helix mimetics for targeting protein-protein interactions. Bioorg. Med. Chem. Lett. 2007, 17, 4641-4645. [CrossRef] [PubMed]

39. Londregan, A.T.; Piotrowski, D.W.; Wei, L. Synthesis of Pyridazine-Based $\alpha$-Helix Mimetics. ACS Comb. Sci. 2016, 18, 651-654. [CrossRef] [PubMed]

40. Moon, H.; Lee, W.S.; Oh, M.; Lee, H.; Lee, J.H.; Im, W.; Lim, H.-S. Design, Solid-Phase Synthesis, and Evaluation of a Phenyl-Piperazine-Triazine Scaffold as $\alpha$-Helix Mimetics. ACS Comb. Sci. 2014, 16, 695-701. [CrossRef] [PubMed]

41. Van Mileghem, S.; Egle, B.; Gilles, P.; Veryser, C.; Van Meervelt, L.; De Borggraeve, W.M. Carbonylation as a novel method for the assembly of pyrazine based oligoamide alpha-helix mimetics. Org. Biomol. Chem. 2017, 15, 373-378. [CrossRef] [PubMed]

42. Plante, J.P.; Burnley, T.; Malkova, B.; Webb, M.E.; Warriner, S.L.; Edwards, T.A.; Wilson, A.J. Oligobenzamide proteomimetic inhibitors of the p53-hDM2 protein-protein interaction. Chem. Commun. 2009, 5091-5093. [CrossRef] [PubMed] 
43. Azzarito, V.; Prabhakaran, P.; Bartlett, A.I.; Murphy, N.S.; Hardie, M.J.; Kilner, C.A.; Edwards, T.A.; Warriner, S.L.; Wilson, A.J. 2-O-alkylated para-benzamide $\alpha$-helix mimetics: The role of scaffold curvature. Org. Biomol. Chem. 2012, 10, 6469-6472. [CrossRef] [PubMed]

44. Campbell, F.; Plante, J.P.; Edwards, T.A.; Warriner, S.L.; Wilson, A.J. N-alkylated oligoamide alpha-helical proteomimetics. Org. Biomol. Chem. 2010, 8, 2344-2351. [CrossRef] [PubMed]

45. Long, K.; Edwards, T.A.; Wilson, A.J. Microwave assisted solid phase synthesis of highly functionalized $N$-alkylated oligobenzamide $\alpha$-helix mimetics. Bioorg. Med. Chem. 2013, 21, 4034-4040. [CrossRef] [PubMed]

46. Barnard, A.; Long, K.; Yeo, D.J.; Miles, J.A.; Azzarito, V.; Burslem, G.M.; Prabhakaran, P.; Edwards, A.T.; Wilson, A.J. Orthogonal functionalisation of $\alpha$-helix mimetics. Org. Biomol. Chem. 2014, 12, 6794-6799. [CrossRef] [PubMed]

47. Marimganti, S.; Cheemala, M.N.; Ahn, J.-M. Novel Amphiphilic $\alpha$-Helix Mimetics Based on a Bis-benzamide Scaffold. Org. Lett. 2009, 11, 4418-4421. [CrossRef] [PubMed]

48. Thompson, S.; Vallinayagam, R.; Adler, M.J.; Scott, R.T.W.; Hamilton, A.D. Double-sided $\alpha$-helix mimetics. Tetrahedron 2012, 68, 4501-4505. [CrossRef]

49. Thompson, S.; Hamilton, A.D. Amphiphilic $\alpha$-helix mimetics based on a benzoylurea scaffold. Org. Biomol. Chem. 2012, 10, 5780-5782. [CrossRef] [PubMed]

50. Lee, J.H.; Oh, M.; Kim, H.S.; Lee, H.; Im, W.; Lim, H.-S. Converting One-Face $\alpha$-Helix Mimetics into Amphiphilic $\alpha$-Helix Mimetics as Potent Inhibitors of Protein-Protein Interactions. ACS Comb. Sci. 2016, 18, 36-42. [CrossRef] [PubMed]

51. Lanning, M.E.; Wilder, P.T.; Bailey, H.; Drennen, B.; Cavalier, M.; Chen, L.; Yap, J.L.; Raje, M.; Fletcher, S. Towards more drug-like proteomimetics: Two-faced, synthetic $\alpha$-helix mimetics based on a purine scaffold. Org. Biomol. Chem. 2015, 13, 8642-8646. [CrossRef] [PubMed]

52. Lanning, M.; Fletcher, S. Multi-Facial, Non-Peptidic $\alpha$-Helix Mimetics. Biology 2015, 4, 540-555. [CrossRef] [PubMed]

53. Geotti-Bianchini, P.; Moretto, A.; Peggion, C.; Beyrath, J.; Bianco, A.; Formaggio, F. Replacement of Ala by Aib improves structuration and biological stability in thymine-based $\alpha$-nucleopeptides. Org. Biomol. Chem. 2010, 8, 1315-1321. [CrossRef] [PubMed]

54. Kanthala, S.; Gauthier, T.; Satyanarayanajois, S. Structure-activity relationships of peptidomimetics that inhibit PPI of HER2-HER3. Biopolymers 2014, 101, 693-702. [CrossRef] [PubMed]

55. Liu, R.; Li, X.; Shih, T.-C.; Lee, J.S.; Lam, K.S. CHAPTER 10. Peptide Therapeutics: Oncology. In Peptide-Based Drug Discovery: Challenges and New Therapeutics; RSC Publishing: London, UK, 2017; pp. 278-325.

56. Garton, M.; Nim, S.; Stone, T.A.; Wang, K.E.; Deber, C.M.; Kim, P.M. Method to generate highly stable D-amino acid analogs of bioactive helical peptides using a mirror image of the entire PDB. Proc. Natl. Acad. Sci. USA 2018, 115, 1505-1510. [CrossRef] [PubMed]

57. Zhou, N.; Luo, Z.; Luo, J.; Fan, X.; Cayabyab, M.; Hiraoka, M.; Liu, D.; Han, X.; Pesavento, J.; Dong, C.-Z.; et al. Exploring the stereochemistry of CXCR4-peptide recognition and inhibiting HIV-1 entry with D-peptides derived from chemokines. J. Biol. Chem. 2002, 277, 17476-17485. [CrossRef] [PubMed]

58. Checco, J.W.; Lee, E.F.; Evangelista, M.; Sleebs, N.J.; Rogers, K.; Pettikiriarachchi, A.; Kershaw, N.J.; Eddinger, G.A.; Belair, D.G.; Wilson, J.L.; et al. $\alpha / \beta$-Peptide Foldamers Targeting Intracellular Protein-Protein Interactions with Activity in Living Cells. J. Am. Chem. Soc. 2015, 137, 11365-11375. [CrossRef] [PubMed]

59. Funke, S.A.; Willbold, D. Mirror image phage display-A method to generate d-peptide ligands for use in diagnostic or therapeutical applications. Mol. Biosyst. 2009, 5, 783-786. [CrossRef] [PubMed]

60. Tal-Gan, Y.; Freeman, N.S.; Klein, S.; Levitzki, A.; Gilon, C. Metabolic Stability of Peptidomimetics: N-Methyl and Aza Heptapeptide Analogs of a PKB/Akt Inhibitor. Chem. Biol. Drug Des. 2011, 78, 887-892. [CrossRef] [PubMed]

61. McDougall, L.; Draper, E.R.; Beadle, J.D.; Shipman, M.; Raubo, P.; Jamieson, A.G.; Adams, D.J. Enzymatically-stable oxetane-based dipeptide hydrogels. Chem. Commun. 2018, 54, 1793-1796. [CrossRef] [PubMed]

62. Walensky, L.D.; Bird, G.H. Hydrocarbon-stapled peptides: Principles, practice, and progress. J. Med. Chem. 2014, 57, 6275-6288. [CrossRef] [PubMed]

63. Cardote, T.A.F.; Ciulli, A. Cyclic and Macrocyclic Peptides as Chemical Tools To Recognise Protein Surfaces and Probe Protein-Protein Interactions. ChemMedChem 2016, 11, 787-794. [CrossRef] [PubMed] 
64. Sharma, K.; Kunciw, D.L.; Xu, W.; Wiedmann, M.M.; Wu, Y.; Sore, H.F.; Galloway, W.R.J.D.; Lau, Y.H.; Itzhaki, L.S.; Spring, D.R. CHAPTER 8. Double-click Stapled Peptides for Inhibiting Protein-Protein Interactions. In Cyclic Peptides: From Bioorganic Synthesis to Applications; RSC Publishing: London, UK, 2017; pp. 164-187.

65. Dougherty, P.G.; Qian, Z.; Pei, D. Macrocycles as protein-protein interaction inhibitors. Biochem. J. 2017, 474, 1109-1125. [CrossRef] [PubMed]

66. Srinivasan, M. Interface Peptide Mimetics-Rationale and Application as Therapeutic Agents. Med. Chem. 2016, 6, 189-194. [CrossRef]

67. Robertson, N.; Jamieson, A. Regulation of protein-protein interactions using stapled peptides. Rep. Org. Chem. 2015, 5, 65-74.

68. Atzori, A.; Baker, A.E.; Chiu, M.; Bryce, R.A.; Bonnet, P. Effect of Sequence and Stereochemistry Reversal on p53 Peptide Mimicry. PLoS ONE 2013, 8, e68723. [CrossRef] [PubMed]

69. Frackenpohl, J.; Arvidsson, P.I.; Schreiber, J.V.; Seebach, D. The Outstanding Biological Stability of $\beta$ - and $\gamma$-Peptides toward Proteolytic Enzymes: An In Vitro Investigation with Fifteen Peptidases. ChemBioChem 2001, 2, 445-455. [CrossRef]

70. Wiegand, H.; Wirz, B.; Schweitzer, A.; Camenisch, G.P.; Perez, M.I.R.; Gross, G.; Woessner, R.; Voges, R.; Arvidsson, P.I.; Frackenpohl, J.; et al. The outstanding metabolic stability of a 14C-labeled beta-nonapeptide in rats-In vitro and in vivo pharmacokinetic studies. Biopharm. Drug Dispos. 2002, 23, 251-262. [CrossRef] [PubMed]

71. Gao, M.; Cheng, K.; Yin, H. Targeting protein-protein interfaces using macrocyclic peptides. Biopolymers 2015, 104, 310-316. [CrossRef] [PubMed]

72. Villar, E.A.; Beglov, D.; Chennamadhavuni, S.; Porco, J.A.; Kozakov, D.; Vajda, S.; Whitty, A. How proteins bind macrocycles. Nat. Chem. Biol. 2014, 10, 723-731. [CrossRef] [PubMed]

73. Krüger, D.M.; Glas, A.; Bier, D.; Pospiech, N.; Wallraven, K.; Dietrich, L.; Ottmann, C.; Koch, O.; Hennig, S.; Grossmann, T.N. Structure-Based Design of Non-natural Macrocyclic Peptides That Inhibit Protein-Protein Interactions. J. Med. Chem. 2017, 60, 8982-8988. [CrossRef] [PubMed]

74. Gil-Martin, M.; Pardo, P.G.; Lopez-Tarruella, S.; Manso, L.; Perez-Fidalgo, J.A.; Ademuyiwa, F.O.; Mayer, I.A.; Pluard, T.J.; Garcia, M.M.; Kaufman, P.A.; et al. Phase I study of the combination of balixafortide (CXCR4 inhibitor) and eribulin in HER2-negative metastatic breast cancer (MBC) patients (pts). J. Clin. Oncol. 2017, 35, 2555.

75. Von Nussbaum, F.; Li, V.M.-J. Neutrophil elastase inhibitors for the treatment of (cardio)pulmonary diseases: Into clinical testing with pre-adaptive pharmacophores. Bioorg. Med. Chem. Lett. 2015, 25, 4370-4381. [CrossRef] [PubMed]

76. Bennett, G.; Harrison, S.; Campbell, S.; Teufel, D.; Langforn, G.; Watt, A.; Bonny, C. Development of BT1718, a Bicycle Drug Conjugate $($ BDC) targeting MT1-MMP for treatment of solid tumours. Eur. J. Cancer 2016, 69, S21. [CrossRef]

77. Schwameis, R.; Eder, S.; Pietschmann, H.; Fischer, B.; Mascher, H.; Tzotzos, S.; Fischer, H.; Lucas, R.; Zeitlinger, M.; Hermann, R. A FIM Study to Assess Safety and Exposure of Inhaled Single Doses of AP301-A Specific ENaC Channel Activator for the Treatment of Acute Lung Injury. J. Clin. Pharmacol. 2014, 54, 341-350. [CrossRef] [PubMed]

78. Ricardo, A.; Arata, M.; DeMarco, S.; Dhamnaskar, K.; Hammer, R.; Fridkis-Hareli, M.; Rajagopal, V.; Seyb, K.; Tang, G.-Q.; Tobe, S.; et al. Preclinical evaluation of RA101495, a potent cyclic peptide inhibitor of C5 for the treatment of paroxysmal nocturnal hemoglobinuria. Blood 2015, 126, 939.

79. Rennie, Y.K.; McIntyre, P.J.; Akindele, T.; Bayliss, R.; Jamieson, A.G. A TPX2 Proteomimetic Has Enhanced Affinity for Aurora-A Due to Hydrocarbon Stapling of a Helix. ACS Chem. Biol. 2016, 11, 3383-3390. [CrossRef] [PubMed]

80. Ogura, K.; Okamura, H. Conformational change of Sos-derived proline-rich peptide upon binding Grb2 N-terminal SH3 domain probed by NMR. Sci. Rep. 2013, 3, 2913. [CrossRef] [PubMed]

81. Chu, Q.; Moellering, R.E.; Hilinski, G.J.; Kim, Y.-W.; Grossmann, T.N.; Yeh, J.T.-H.; Verdine, G.L. Towards understanding cell penetration by stapled peptides. Med. Chem. Commun. 2015, 6, 111-119. [CrossRef]

82. Scholtz, J.M.; Qian, H.; Robbins, V.H.; Baldwin, R.L. The energetics of ion-pair and hydrogen-bonding interactions in a helical peptide. Biochemistry 1993, 32, 9668-9676. [CrossRef] [PubMed] 
83. Marqusee, S.; Baldwin, R.L. Helix stabilization by Glu-...Lys+ salt bridges in short peptides of de novo design. Proc. Natl. Acad. Sci. USA 1987, 84, 8898-8902. [CrossRef] [PubMed]

84. Chorev, M.; Roubini, E.; McKee, R.L.; Gibbons, S.W.; Goldman, M.E.; Caulfield, M.P.; Rosenblatt, M. Cyclic parathyroid hormone-related protein antagonists: Lysine 13 to aspartic acid 17 [i to (i+4)] side chain to side chain lactamization. Biochemistry 1991, 30, 5968-5974. [CrossRef] [PubMed]

85. Houston, M.E.; Gannon, C.L.; Kay, C.M.; Hodges, R.S. Lactam bridge stabilization of alpha-helical peptides: Ring size, orientation and positional effects. J. Pept. Sci. 1995, 1, 274-282. [CrossRef] [PubMed]

86. Klein, M.J.; Schmidt, S.; Wadhwani, P.; Bürck, J.; Reichert, J.; Afonin, S.; Berditsch, M.; Schober, T.; Brock, R.; Kansy, M.; et al. Lactam-Stapled Cell-Penetrating Peptides: Cell Uptake and Membrane Binding Properties. J. Med. Chem. 2017, 60, 8071-8082. [CrossRef] [PubMed]

87. Kawamoto, S.A.; Coleska, A.; Ran, X.; Yang, C.-Y.; Wang, S. Design of Triazole-Stapled BCL9 $\alpha$-Helical Peptides to Target the $\beta$-Catenin/B-Cell CLL/lymphoma 9 (BCL9) Protein-Protein Interaction. J. Med. Chem. 2012, 55, 1137-1146. [CrossRef] [PubMed]

88. Walensky, L.D.; Kung, A.L.; Escher, I.; Malia, T.J.; Barbuto, S.; Wright, R.D.; Wagner, G.; Verdine, G.L.; Korsmeyer, S.J. Activation of apoptosis in vivo by a hydrocarbon-stapled BH3 helix. Science 2004, 305, 1466-1470. [CrossRef] [PubMed]

89. Bernal, F.; Tyler, A.F.; Korsmeyer, S.J.; Walensky, L.D.; Verdine, G.L. Reactivation of the p53 tumor suppressor pathway by a stapled p53 peptide. J. Am. Chem. Soc. 2007, 129, 2456-2457. [CrossRef] [PubMed]

90. Kim, Y.-W.; Kutchukian, P.S.; Verdine, G.L. Introduction of all-hydrocarbon i,i+3 staples into alpha-helices via ring-closing olefin metathesis. Org. Lett. 2010, 12, 3046-3049. [CrossRef] [PubMed]

91. Kim, Y.-W.; Grossmann, T.N.; Verdine, G.L. Synthesis of all-hydrocarbon stapled $\alpha$-helical peptides by ring-closing olefin metathesis. Nat. Protoc. 2011, 6, 761-771. [CrossRef] [PubMed]

92. Bird, G.H.; Bernal, F.; Pitter, K.; Walensky, L.D. Synthesis and biophysical characterization of stabilized alpha-helices of BCL-2 domains. Methods Enzymol. 2008, 446, 369-386. [PubMed]

93. LaBelle, J.L.; Katz, S.G.; Bird, G.H.; Gavathiotis, E.; Stewart, M.L.; Lawrence, C.; Fisher, J.K.; Godes, M.; Pitter, K.; Kung, A.L.; et al. A stapled BIM peptide overcomes apoptotic resistance in hematologic cancers. J. Clin. Investig. 2012, 122, 2018-2031. [CrossRef] [PubMed]

94. Shepherd, N.E.; Hoang, H.N.; Abbenante, G.; Fairlie, D.P. Single turn peptide alpha helices with exceptional stability in water. J. Am. Chem. Soc. 2005, 127, 2974-2983. [CrossRef] [PubMed]

95. Shepherd, N.E.; Abbenante, G.; Fairlie, D.P. Consecutive Cyclic Pentapeptide Modules Form Short $\alpha$-Helices that are Very Stable to Water and Denaturants. Angew. Chem. Int. Ed. 2004, 43, 2687-2690. [CrossRef]

96. Harrison, R.S.; Ruiz-Gómez, G.; Hill, T.A.; Chow, S.Y.; Shepherd, N.E.; Lohman, R.-J.; Abbenante, G.; Hoang, H.N.; Fairlie, D.P. Novel Helix-Constrained Nociceptin Derivatives Are Potent Agonists and Antagonists of ERK Phosphorylation and Thermal Analgesia in Mice. J. Med. Chem. 2010, 53, 8400-8408. [CrossRef] [PubMed]

97. Kolb, H.C.; Finn, M.G.; Sharpless, K.B. Click Chemistry: Diverse Chemical Function from a Few Good Reactions. Angew. Chem. Int. Ed. 2001, 40, 2004-2021. [CrossRef]

98. Tornøe, C.W.; Christensen, C.; Meldal, M. Peptidotriazoles on solid phase: [1,2,3]-Triazoles by regiospecific copper(I)-catalyzed 1,3-dipolar cycloadditions of terminal alkynes to azides. J. Org. Chem. 2002, 67, 3057-3064. [CrossRef] [PubMed]

99. Yamagishi, Y.; Ashigai, H.; Goto, Y.; Murakami, H.; Suga, H. Ribosomal Synthesis of Cyclic Peptides with a Fluorogenic Oxidative Coupling Reaction. ChemBioChem 2009, 10, 1469-1472. [CrossRef] [PubMed]

100. Miller, S.J.; Grubbs, R.H. Synthesis of Conformationally Restricted Amino Acids and Peptides Employing Olefin Metathesis. J. Am. Chem. Soc. 1995, 117, 5855-5856. [CrossRef]

101. Miller, S.J.; Blackwell, H.E.; Grubbs, R.H. Application of Ring-Closing Metathesis to the Synthesis of Rigidified Amino Acids and Peptides. J. Am. Chem. Soc. 1996, 118, 9606-9614. [CrossRef]

102. Blackwell, H.E.; Grubbs, R.H. Highly Efficient Synthesis of Covalently Cross-Linked Peptide Helices by Ring-Closing Metathesis. Angew. Chem. Int. Ed. 1998, 37, 3281-3284. [CrossRef]

103. Schafmeister, C.E.; Po, J.; Verdine, G.L. An All-Hydrocarbon Cross-Linking System for Enhancing the Helicity and Metabolic Stability of Peptides. J. Am. Chem. Soc. 2000, 122, 5891-5892. [CrossRef]

104. Walensky, L.D.; Pitter, K.; Morash, J.; Oh, K.J.; Barbuto, S.; Fisher, J.; Smith, E.; Verdine, G.L.; Korsmeyer, S.J. A stapled BID BH3 helix directly binds and activates BAX. Mol. Cell 2006, 24, 199-210. [CrossRef] [PubMed] 
105. Verdine, G.L.; Hilinski, G.J. Stapled peptides for intracellular drug targets. Methods Enzymol. 2012, 503, 3-33. [PubMed]

106. Aillard, B.; Robertson, N.S.; Baldwin, A.R.; Robins, S.; Jamieson, A.G. Robust asymmetric synthesis of unnatural alkenyl amino acids for conformationally constrained $\alpha$-helix peptides. Org. Biomol. Chem. 2014, 12, 8775-8782. [CrossRef] [PubMed]

107. Yeo, D.J.; Warriner, S.L.; Wilson, A.J. Monosubstituted alkenyl amino acids for peptide "stapling". Chem. Commun. 2013, 49, 9131-9133. [CrossRef] [PubMed]

108. McWhinnie, F.S.; Sepp, K.; Wilson, C.; Kunath, T.; Hupp, T.R.; Baker, T.S.; Houston, D.R.; Hulme, A.N. Mono-Substituted Hydrocarbon Diastereomer Combinations Reveal Stapled Peptides with High Structural Fidelity. Chem. A Eur. J. 2018, 24, 2094-2097. [CrossRef] [PubMed]

109. Shim, S.Y.; Kim, Y.-W.; Verdine, G.L. A new i, i +3 peptide stapling system for $\alpha$-helix stabilization. Chem. Biol. Drug Des. 2013, 82, 635-642. [CrossRef] [PubMed]

110. Bird, G.H.; Madani, N.; Perry, A.F.; Princiotto, A.M.; Supko, J.G.; He, X.; Gavathiotis, E.; Sodroski, J.G.; Walensky, L.D. Hydrocarbon double-stapling remedies the proteolytic instability of a lengthy peptide therapeutic. Proc. Natl. Acad. Sci. USA 2010, 107, 14093-14098. [CrossRef] [PubMed]

111. Hilinski, G.J.; Kim, Y.-W.; Hong, J.; Kutchukian, P.S.; Crenshaw, C.M.; Berkovitch, S.S.; Chang, A.; Ham, S.; Verdine, G.L. Stitched $\alpha$-helical peptides via bis ring-closing metathesis. J. Am. Chem. Soc. 2014, 136, 12314-12322. [CrossRef] [PubMed]

112. Grigoryev, Y. Stapled peptide to enter human testing, but affinity questions remain. Nat. Med. 2013, 19, 120. [CrossRef] [PubMed]

113. Payton, M.; Pinchasik, D.; Mehta, A.; Goel, S.; Zain, J.M.; Sokol, L.; Jacobsen, E.; Patel, M.R.; Horwitz, S.M.; Meric-Bernstam, F.; et al. Phase 2a study of a novel stapled peptide ALRN-6924 disrupting MDMX- and MDM2-mediated inhibition of wild-type TP53 in patients with peripheral t-cell lymphoma. Ann. Oncol. 2017, 28, v355-v371. [CrossRef]

114. Meric-Bernstam, F.; Saleh, M.N.; Infante, J.R.; Goel, S.; Falchook, G.S.; Shapiro, G. Phase I trial of a novel stapled peptide ALRN-6924 disrupting MDMX- and MDM2-mediated inhibition of WT p53 in patients with solid tumors and lymphomas. J. Clin. Oncol. 2017, 26, 153-160.

115. Kumita, J.R.; Smart, O.S.; Woolley, G.A. Photo-control of helix content in a short peptide. Proc. Natl. Acad. Sci. USA 2000, 97, 3803-3808. [CrossRef] [PubMed]

116. Flint, D.G.; Kumita, J.R.; Smart, O.S.; Woolley, G.A. Using an Azobenzene Cross-Linker to Either Increase or Decrease Peptide Helix Content upon Trans-to-Cis Photoisomerization. Chem. Biol. 2002, 9, 391-397. [CrossRef]

117. Woolley, G.A. Photocontrolling peptide $\alpha$ helices. Acc. Chem. Res. 2005, 38, 486-493. [CrossRef] [PubMed]

118. Kneissl, S.; Loveridge, E.J.; Williams, C.; Crump, M.P.; Allemann, R.K. Photocontrollable peptide-based switches target the anti-apoptotic protein Bcl-xL. Chembiochem 2008, 9, 3046-3054. [CrossRef] [PubMed]

119. Wang, Y.; Chou, D.H.-C. A Thiol-Ene Coupling Approach to Native Peptide Stapling and Macrocyclization. Angew. Chem. Int. Ed. 2015, 54, 10931-10934. [CrossRef] [PubMed]

120. Jo, H.; Meinhardt, N.; Wu, Y.; Kulkarni, S.; Hu, X.; Low, K.E.; Davies, P.L.; DeGrado, W.F.; Greenbaum, D.C. Development of $\alpha$-helical calpain probes by mimicking a natural protein-protein interaction. J. Am. Chem. Soc. 2012, 134, 17704-17713. [CrossRef] [PubMed]

121. Peraro, L.; Zou, Z.; Makwana, K.M.; Cummings, A.E.; Ball, H.L.; Yu, H.; Lin, Y.-S.; Levine, B.; Kritzer, J.A. Diversity-Oriented Stapling Yields Intrinsically Cell-Penetrant Inducers of Autophagy. J. Am. Chem. Soc. 2017, 139, 7792-7802. [CrossRef] [PubMed]

122. Rojas, A.J.; Zhang, C.; Vinogradova, E.V.; Buchwald, N.H.; Reilly, J.; Pentelute, B.L.; Buchwald, S.L. Divergent unprotected peptide macrocyclisation by palladium-mediated cysteine arylation. Chem. Sci. 2017, 8, 4257-4263. [CrossRef] [PubMed]

123. St. Louis, L.E.; Rodriguez, T.M.; Waters, M.L. A study of 2-component i, i +3 peptide stapling using thioethers. Bioorg. Med. Chem. 2018, 26, 1203-1205.

124. Micewicz, E.D.; Sharma, S.; Waring, A.J.; Luong, H.T.; McBride, W.H.; Ruchala, P. Bridged Analogues for p53-Dependent Cancer Therapy Obtained by S-Alkylation. Int. J. Pept. Res. Ther. 2016, 22, 67-81. [CrossRef] [PubMed]

125. Spokoyny, A.M.; Zou, Y.; Ling, J.J.; Yu, H.; Lin, Y.-S.; Pentelute, B.L. A Perfluoroaryl-Cysteine SNAr Chemistry Approach to Unprotected Peptide Stapling. J. Am. Chem. Soc. 2013, 135, 5946-5949. [CrossRef] [PubMed] 
126. Brown, S.P.; Smith, A.B. Peptide/Protein Stapling and Unstapling: Introduction of s-Tetrazine, Photochemical Release, and Regeneration of the Peptide/Protein. J. Am. Chem. Soc. 2015, 137, 4034-4037. [CrossRef] [PubMed]

127. Lautrette, G.; Touti, F.; Lee, H.G.; Dai, P.; Pentelute, B.L. Nitrogen Arylation for Macrocyclization of Unprotected Peptides. J. Am. Chem. Soc. 2016, 138, 8340-8343. [CrossRef] [PubMed]

128. Hui, E.Y.-L.; Rout, B.; Tan, Y.S.; Verma, C.S.; Chan, K.-P.; Johannes, C.W. An intramolecular tryptophancondensation approach for peptide stapling. Org. Biomol. Chem. 2018, 16, 389-392. [CrossRef] [PubMed]

129. Lau, Y.H.; de Andrade, P.; Quah, S.-T.; Rossmann, M.; Laraia, L.; Sköld, N.; Sum, T.J.; Rowling, P.J.E.; Joseph, T.L.; Verma, C.; et al. Functionalised staple linkages for modulating the cellular activity of stapled peptides. Chem. Sci. 2014, 5, 1804-1809. [CrossRef]

130. Wu, Y.; Olsen, L.B.; Lau, Y.H.; Jensen, C.H.; Rossmann, M.; Baker, Y.R.; Sore, H.F.; Collins, S.; Spring, D.R. Development of a Multifunctional Benzophenone Linker for Peptide Stapling and Photoaffinity Labelling. ChemBioChem 2016, 17, 689-692. [CrossRef] [PubMed]

131. Wu, Y.; Villa, F.; Maman, J.; Lau, Y.H.; Dobnikar, L.; Simon, A.C.; Labib, K.; Spring, D.R.; Pellegrini, L. Targeting the Genome-Stability Hub Ctf4 by Stapled-Peptide Design. Angew. Chem. Int. Ed. 2017, 56, 12866-12872. [CrossRef] [PubMed]

132. Lau, Y.H.; Wu, Y.; Rossmann, M.; Tan, B.X.; de Andrade, P.; Tan, Y.S.; Verma, C.; McKenzie, G.J.; Venkitaraman, A.R.; Hyvönen, M.; et al. Double Strain-Promoted Macrocyclization for the Rapid Selection of Cell-Active Stapled Peptides. Angew. Chem. Int. Ed. 2015, 54, 15410-15413. [CrossRef] [PubMed]

133. Zhang, L.; Navaratna, T.; Liao, J.; Thurber, G.M. Dual-Purpose Linker for Alpha Helix Stabilization and Imaging Agent Conjugation to Glucagon-Like Peptide-1 Receptor Ligands. Bioconjug. Chem. 2015, 26, 329-337. [CrossRef] [PubMed]

134. Boutureira, O.; Bernardes, G.J.L. Advances in Chemical Protein Modification. Chem. Rev. 2015, 115, $2174-2195$. [CrossRef] [PubMed]

135. Fairlie, D.P.; De Araujo, A.D. Review Stapling Peptides Using Cysteine Crosslinking. Pept. Sci. 2016, 106, 843-852. [CrossRef] [PubMed]

136. Zhang, F.; Sadovski, O.; Xin, S.J.; Woolley, G.A. Stabilization of folded peptide and protein structures via distance matching with a long, rigid cross-linker. J. Am. Chem. Soc. 2007, 129, 14154-14155. [CrossRef] [PubMed]

137. Mart, R.J.; Allemann, R.K. Azobenzene photocontrol of peptides and proteins. Chem. Commun. 2016, 52, 12262-12277. [CrossRef] [PubMed]

138. Heinis, C.; Rutherford, T.; Freund, S.; Winter, G. Phage-encoded combinatorial chemical libraries based on bicyclic peptides. Nat. Chem. Biol. 2009, 5, 502-507. [CrossRef] [PubMed]

139. Angelini, A.; Cendron, L.; Chen, S.; Touati, J.; Winter, G.; Zanotti, G.; Heinis, C. Bicyclic Peptide Inhibitor Reveals Large Contact Interface with a Protease Target. ACS Chem. Biol. 2012, 7, 817-821. [CrossRef] [PubMed]

140. Chen, S.; Bertoldo, D.; Angelini, A.; Pojer, F.; Heinis, C. Peptide Ligands Stabilized by Small Molecules. Angew. Chem. Int. Ed. 2014, 53, 1602-1606. [CrossRef] [PubMed]

141. Assem, N.; Ferreira, D.J.; Wolan, D.W.; Dawson, P.E. Acetone-Linked Peptides: A Convergent Approach for Peptide Macrocyclization and Labeling. Angew. Chem. Int. Ed. 2015, 54, 8665-8668. [CrossRef] [PubMed]

142. Grison, C.M.; Burslem, G.M.; Miles, J.A.; Pilsl, L.K.A.; Yeo, D.J.; Imani, Z.; Warriner, S.L.; Webb, M.E.; Wilson, A.J. Double quick, double click reversible peptide "stapling". Chem. Sci. 2017, 8, 5166-5171. [CrossRef] [PubMed]

143. Li, Z.; Huang, R.; Xu, H.; Chen, J.; Zhan, Y.; Zhou, X.; Chen, H.; Jiang, B. Divinylsulfonamides as Specific Linkers for Stapling Disulfide Bonds in Peptides. Org. Lett. 2017, 19, 4972-4975. [CrossRef] [PubMed]

144. Lau, Y.H.; Wu, Y.; de Andrade, P.; Galloway, W.R.J.D.; Spring, D.R. A two-component "double-click" approach to peptide stapling. Nat. Protoc. 2015, 10, 585-594. [CrossRef] [PubMed]

145. Lau, Y.H.; de Andrade, P.; McKenzie, G.J.; Venkitaraman, A.R.; Spring, D.R. Linear Aliphatic Dialkynes as Alternative Linkers for Double-Click Stapling of p53-Derived Peptides. ChemBioChem 2014, 15, 2680-2683. [CrossRef] [PubMed]

146. Lau, Y.H.; de Andrade, P.; Sköld, N.; McKenzie, G.J.; Venkitaraman, A.R.; Verma, C.; Lane, D.P.; Spring, D.R.; Lukacs, C.; Klein, C.; et al. Investigating peptide sequence variations for "double-click" stapled p53 peptides. Org. Biomol. Chem. 2014, 12, 4074-4077. [CrossRef] [PubMed] 
147. Wiedmann, M.M.; Tan, Y.S.; Wu, Y.; Aibara, S.; Xu, W.; Sore, H.F.; Verma, C.S.; Itzhaki, L.; Stewart, M.; Brenton, J.D.; et al. Development of Cell-Permeable, Non-Helical Constrained Peptides to Target a Key Protein-Protein Interaction in Ovarian Cancer. Angew. Chem. Int. Ed. 2017, 56, 524-529. [CrossRef] [PubMed]

148. Xu, W.; Lau, Y.H.; Fischer, G.; Tan, Y.S.; Chattopadhyay, A.; de la Roche, M.; Hyvönen, M.; Verma, C.; Spring, D.R.; Itzhaki, L.S. Macrocyclized Extended Peptides: Inhibiting the Substrate-Recognition Domain of Tankyrase. J. Am. Chem. Soc. 2017, 139, 2245-2256. [CrossRef] [PubMed]

149. Zhang, L.; Navaratna, T.; Thurber, G.M. A Helix-Stabilizing Linker Improves Subcutaneous Bioavailability of a Helical Peptide Independent of Linker Lipophilicity. Bioconjug. Chem. 2016, 27, 1663-1672. [CrossRef] [PubMed]

150. Tran, P.T.; Larsen, C.Ø.; Røndbjerg, T.; de Foresta, M.; Kunze, M.B.A.; Marek, A.; Løper, J.H.; Boyhus, L.-E.; Knuhtsen, A.; Lindorff-Larsen, K.; et al. Diversity-Oriented Peptide Stapling: A Third Generation CopperCatalysed Azide-Alkyne Cycloaddition Stapling and Functionalisation Strategy. Chem. A Eur. J. 2017, 23, 3490-3495. [CrossRef] [PubMed]

(C) 2018 by the authors. Licensee MDPI, Basel, Switzerland. This article is an open access article distributed under the terms and conditions of the Creative Commons Attribution (CC BY) license (http:/ / creativecommons.org/licenses/by/4.0/). 